\title{
Allogeneic hematopoietic stem cell transplantation for inherited bone marrow failure syndromes
}

\author{
Jean-Hugues Dalle ${ }^{1}$ Régis Peffault de Latour ${ }^{2}$
}

Received: 26 December 2015 / Revised: 7 January 2016 / Accepted: 13 January 2016 / Published online: 12 February 2016

(C) The Japanese Society of Hematology 2016

\begin{abstract}
Inherited bone marrow failure (IBMF) syndromes are a heterogeneous group of rare hematological disorders characterized by the impairment of hematopoiesis, which harbor specific clinical presentations and pathogenic mechanisms. Some of these syndromes may progress through clonal evolution, myelodysplastic syndrome (MDS) and acute myeloid leukemia (AML). Most prominent are failures of DNA repair such as Fanconi Anemia and much rarer failure of ribosomal apparatus, e.g., Diamond Blackfan Anemia or of telomere elongation such as dyskeratosis congenita. In these congenital disorders, hematopoietic stem cell transplantation (HSCT) is often a consideration. However, HSCT will not correct the underlying disease and possible co-existing extra-medullary (multi)-organ defects, but will improve BMF. Indications as well as transplantation characteristics are most of the time controversial in this setting because of the rarity of reported cases. The present paper proposes a short overview of current practices.
\end{abstract}

Keywords Inherited bone marrow failure disorders . Pediatrics $\cdot$ Stem cell transplantation

Jean-Hugues Dalle

jhugues.dalle@gmail.com

1 Service d'Hémato-immunologie, Hôpital Robert-Debré, AP-HP et Université Paris 7-Paris Diderot, Paris, France

2 Service d'Hématologie Greffe, Hôpital Saint-Louis, AP-HP et Université Paris 7-Paris Diderot, Paris, France

\section{Introduction}

Inherited bone marrow failure (IBMF) syndromes are a heterogeneous group of rare hematological disorders characterized by the impairment of hematopoiesis, which harbor specific clinical presentations and pathogenic mechanisms. Some of these syndromes may progress through clonal evolution, myelodysplastic syndrome (MDS) and acute myeloid leukemia (AML). Most prominent are failures of DNA repair such as Fanconi Anemia (FA) and much rarer failure of ribosomal apparatus, e.g., Diamond Blackfan Anemia (DBA) or of telomere elongation such as dyskeratosis congenita (DC) [1]. Improving diagnostic precision, care and syndrome definitions using comprehensive nextgeneration sequencing for the inherited bone marrow failure syndromes are required [2]. Genomic analysis of bone marrow failure and myelodysplastic syndromes reveals phenotypic and diagnostic complexity. In these congenital disorders, hematopoietic stem cell transplantation (HSCT) is often a consideration. HSCT will not correct the underlying disease and possible co-existing extra-medullary (multi)-organ defects but will improve BMF. Some of these IBMF syndromes are associated with an increased risk of solid tumor later on. This risk is not corrected as well by HSCT and may be enhanced by HSCT procedure, from the conditioning regimen to the chronic graft-versus-host disease (GvHD) appearance. Due to both uncertainties and median and long-term peculiar side-effects, indications to transplant and use of transplant technology should be performed in specialized centers because of susceptibilities to toxicity and needed specific management during and after HSCT particularly regarding long-term toxicity and namely secondary cancers. However, it is still difficult nowadays to clearly identify when and how to transplant those particular rare and heterogeneous disorders. 
The present paper thus summarizes the key information regarding HSCT in the main inherited BMF.

\section{Fanconi anemia (FA)}

Although Fanconi anemia (FA) is the most frequent IBFM syndrome, this syndrome is a rare, phenotypically heterogeneous, inherited disorder clinically characterized by congenital abnormalities (renal, cardiac, bone, ear, etc....), progressive BMF and a predisposition to develop malignancies [3]. More than 18 FA genes have been identified, the most frequently seen being FANCA, FANCC, FANCG, and FANCD2 [4, 5]. BRCA2/FANCD1 and PALB2/ FANCN mutations, who tend to develop MDS, AML and/ or solid cancers (particularly Wilms' tumors and medulloblastomas) very early during childhood are responsible of the more severe forms of this syndrome. HSCT still represents the only curative option for BMF in FA [6-9], but still exposed patients to a higher risk of secondary cancers [10-12]. FA physicians have agreed on consensus treatment guidelines for severe BMF or transformation: persistent hemoglobin $<8 \mathrm{~g} / \mathrm{dL}$, platelets $<30,000 / \mathrm{mm}^{3}$, absolute neutrophil count $<500 / \mathrm{mm}^{3}$, overt leukemia with at least $20 \%$ blasts in the marrow, or morphologic MDS. Adapted conditioning regimens with reduced doses of cyclophosphamide (with or without limited field radiotherapy), have cured FA related BMF in numbers of patients transplanted from a matched related family donor $[6,13,14]$. Published results on unrelated donor (UD) HSCT were less encouraging for long time, mainly because of an increased risk of graft failure, as well as higher incidences of both acute and chronic graft-versus-host disease (GvHD) [7, 15, 16]. However, better results have been recently reported in this setting $[17,18]$ with $94 \% 5$-year overall survival in the recent paper from MacMillan in patients transplanted without a history of opportunistic infections or transfusions. The use of fludarabine-based reduced intensity conditioning regimens with or without T-cell depletion seems to contribute to this improvement $[8,9,18-22]$.

The optimal time for HSCT is probably when transfusion dependency occurs and prior to $20 \mathrm{red}$ cell and/or single platelet transfusions, before androgen therapy, and before the development of clonal evolution (MDS or leukemia). All patients should undergo a bone marrow aspirate with cytogenetic evaluation every year to detect early dysplastic changes or cytogenetic abnormalities [23].

To avoid transfusions, standard risk patients $(<18$ years of age, good organ function, absence of advanced MDS or leukemia) should undergo HSCT when persistent and moderately severe cytopenia develops (i.e., hemoglobin $<8 \mathrm{~g} /$ $\mathrm{dL}$; absolute neutrophil count $<0.5 \times 10^{9}$ per liter; and/or platelet count $<30 \mathrm{G} / \mathrm{l}$ ). Patients with evidence of advanced MDS or leukemia should also be considered. Earlier transplantation may be considered for patients with specific mutations deemed to be particularly high risk for rapid progression to MDS or leukemia and poor survival (e.g., -7 or $-3 q$ cytogenetic abnormalities or presence of biallelic breast cancer [BRCA] gene mutations).

A matched sibling donor is still the best choice, although significant improvement has been reported with unrelated donor transplantation in the more recent era, especially from $8 / 8$ matched unrelated donor $[8,9,17,20]$. Related $6 / 6$ matched cord blood is also a reasonable option. Every related donor has to be systematically tested for FA before HSCT schedule. Unrelated $6 / 6$ matched cord blood might be considered in case of more than $3 \times 10^{7}$ nucleated cells per kilogram before freezing [24]. Mismatch unrelated donors (less than 10/10), haplo-identical HSCT, as well as the use of 1 or 2 cord blood units with 1 or 2 HLA-disparities regardless of the number of cells should be done in experimented centers within clinical prospective trials only.

Regarding the source of stem cells, bone marrow has been shown to be superior to peripheral blood in patients with acquired aplastic anemia undergoing a matched sibling or unrelated transplant [25-27]. Similar results have been recently published regarding patients with FA [17, 20]. These results are important enough to consider marrow as the recommended source of stem cells in this particular population.

Preparative regimens for HSCT in patients with FA have been modified from standard approaches because of the chromosomal instability present in all FA cells, including non-hematopoietic tissues. A reduced intensity conditioning regimen has to be used with reduced-dose cyclophosphamide (20-40 mg/Kg total dose) to prevent toxicity. The use of fludarabine with or without T-cell depletion contributed to the significant improvement observed in the recent period $[8,9,18,19,21,22,28]$. Irradiation should not be added to avoid an additional risk factor interacting with the main biologic defect of FA (i.e., DNA repair processes). However, low-dose Total Body Irradiation (i.e., TBI 2-3 grays) may be used in specific situations with a high risk of rejection (high burden transfusion history and unrelated donors). Historically, the prognosis appears (very) poor for patients with clonal evolution (i.e., myelodysplastic syndrome, acute myeloid leukemia) at time of transplantation. However, a recent study suggested using a sequential approach in this setting [29]. This latter attitude should be used in case of blasts count $\geq 10 \%$. Below this threshold, patients should be treated according to previous recommendations, with no additional chemotherapy preceding HSCT.

FA patients had an increased risk of experiencing acute GvHD when compared with patients with idiopathic aplastic anemia, leading to a substantially higher rate of treatment related mortality and for those patients who survive higher cumulative rate of cGVHD and higher risk 
of developing secondary malignancies $[11,16,20]$. An intense GvHD prophylaxis should thus be proposed. There is no evidence in the literature whether adding methotrexate or mycophenolate mofetil to cyclosporine A lead to better results. The use of antithymocyte globulins as an in vivo T-cell depletion method has been shown to dramatically reduce the incidence of acute GvHD while ex vivo T-cell depletion is currently under investigation [30]. However, these two attractive approaches deserve attention with respect to the potential risk of increasing the immune deficiency during the first month post-HSCT, leading to higher transplantation-related morbidity and mortality due to opportunistic infections and graft rejections, and should thus be reserved to the unrelated donor setting. Finally, it appears not safe to apply post-transplant cyclophosphamide technique in FA patients.

\section{Severe congenital neutropenia (SCN) (excluding GATA-2 mutations)}

Severe congenital neutropenia ( $\mathrm{SCN}$ ) is a rare and heterogeneous inherited hematologic disorder characterized by profound neutropenia diagnosed early in life and complicated by recurrent severe and life-threatening bacterial infections [31]. SCN is often caused by mutations of the ELA2 gene, HAX1 gene or, less frequently, of the GFI1 gene [32-36]. Other major complications are clonal evolution (leukemia and MDS), affecting about $10 \%$ of patients [37]. The use of G-CSF therapy has radically changed patients' outcomes [38]. Allogeneic hematopoietic stem cell transplantation (HSCT) is still the only curative treatment for selected patients. Validated indications of transplantation include G-CSF resistance ( $>20 \mu \mathrm{g} / \mathrm{kg} /$ day) even in the absence of infections and clonal evolution [39-42].

In patients with neutropenia dependent on chronically high doses of G-CSF (at least $10 \mu \mathrm{g} / \mathrm{kg}$ per injection at least 3 months a year), HSCT should be discussed given the high risk of clonal evolution (Donadieu Haematologica 2005), especially in case of recurrent bacterial infections and if a matched family donor is available. Reported cases of SCN patients who have undergone HSCT include no more than 100 patients worldwide [43]. Because of the high heterogeneity of the published reports (different conditioning regimen, source of stem cells, donor type, disease stage at transplantation) and the small number of reported patients, it is difficult to draw general conclusions or recommendations.

However, as for FA patients and for any patient presenting IBMF, a healthy matched sibling donor is the best option. Matched (10/10) unrelated donor, as well as related 6/6 matched cord blood is also a reasonable option where mismatch unrelated donors (less than 10/10), haplo-identical HSCT, as well as the use of unrelated cord blood with
0, 1 or 2 HLA-disparities regardless of the number of cells should be done in experimented centers within clinical prospective trials only. To avoid an increased risk of GVHD, it is mandatory for using bone marrow as stem cell source. The great majority of published cases received a myeloablative conditioning regimen prior to the first HSCT, usually with busulfan and cyclophosphamide combination [40]. This regimen was effective, with rare graft failure and full chimerism was obtained for almost all patients. Treosulfan and thiotepa were also used. EBMT group recently reported the results from $136 \mathrm{SCN}$ patents transplanted from 1990 and 2012. 61 were transplanted from matched related donor and 14 from mismatched donors. The 3-year overall survival was $82 \%$ and TRM $17 \%$. In multivariate analysis, HSCT below 10 years of age from matched related or unrelated donor in the recent years appeared as good prognostic factors. Chronic GVHD cumulative incidence was significantly higher in patients transplanted with PBSC [41]. Less toxic, non-myeloablative, fludarabine-based, conditioning regimens might reduce transplanted-related mortality, but experience is still very little [44]. TBI should be avoided because of the risk of long-term complications.

In case of clonal evolution, the need for chemotherapy prior to HSCT is controversial [45]. Overall, this approach should be dedicated to patients with overt leukemia, but it can be deleterious in other patients (i.e., patients with MDS) as it may contribute to increasing infection risk [40, 43, 46, 47]. Ebihara, et al. described recently the evolution for $2 \mathrm{SCN}$ patients transplanted for acute myeloid leukemia without prior intensive chemotherapy [48].

\section{Shwachman-diamond syndrome (SDS)}

Shwachman-Diamond Syndrome (SDS) is a multisystemic autosomal recessive disorder, phenotypically heterogeneous characterized by exocrine pancreatic dysfunction, bone metaphyseal dysostosis, mild intellectual retardation, and variable neutropenia [49]. Almost all patients have a mutation in the SBDS gene located on chromosome 7 [50]. BMF and clonal evolution (Acute leukemia \& MDS) are the main life-threatening complications. HSCT is currently the only potentially curative treatment for those patients. The major challenge is to identify patients who are at high risk of hematological complications and may benefit from HSCT. The French group proposed a classification of the severity of SDS based on the first blood counts (ANC $<$ or $\geq 0.5 \times 109 / \mathrm{L} ; \mathrm{Hb}<$ or $\geq 9 \mathrm{~g} / \mathrm{dL}$ and platelet count $<$ or $\geq 100 \times 109 / \mathrm{L}$ ) and on the age at diagnosis ( $<$ or $\geq 3$ months). Patients diagnosed with SDS before the age of 3 months and with low values of hematologic parameters at diagnosis have a higher risk of major hematological complications than patients diagnosed after the age of 3 months and without low values of $\mathrm{CBC}$, or with 
only one of these features. These results, once validated by future studies, will offer a simple way to identify patients, at time of diagnosis, at high risk of severe hematological complications who may be considered for HSCT [39, 51].

Considering HSCT by itself, the recommendations are not different from SCN patients without SDS. However, complications from HSCT are more common in SDS patients than in patients with idiopathic blood dyscrasias [52]. However, some authors have proposed to use attenuated conditioning regimen has been proposed to limit toxicity [53].

\section{Diamond Blackfan anemia (DBA)}

DBA is a autosomal dominant IBMF characterized by a non regenerative and often macrocytic anemia with erythroblastopenia. The penetrance was variable. Some patients present cranio-facial abnormalities in addition to BMF. Disease-causing mutations are identified in $40-45 \%$ of patients and all involved genes code for ribosomal proteins. DBA patients may present higher risk of leukemia or MDS. During the first year of life, therapy is represented by regular transfusion program. After 12 months of age, steroids have to be tried, but only some patients experience response. The absence of response to steroids was defined the absence of reticulocyte count increase after two different periods of steroid therapy.

HSCT represents the only curative option. However, there is always the option of RBC transfusions in view of the relative easy chelation approach available today, and the option of transplant should be discussed with the family.

HSCT has to be proposed to steroid-refractory patients and may be discussed in patients responder, but dependant to steroid therapy above $0.3 \mathrm{mg} / \mathrm{kg} / \mathrm{d}$ or transfusion dependant $[54,55]$.

It appears better to perform HSCT before the age of 10 years and preferably between the ages of 2 and 5 years. There are enough data to recommend sibling donor as evidenced-based. There are too few reported cases with unrelated donor or mismatch donors (Haplo-identical or cord blood transplantation), then panel was not able to recommend any other type of donor than sibling. Bone marrow should thus be preferred to decrease the risk of chronic GVHD. There are few available data then the use of standard HSCT myeloablative conditioning regimen based on fludarabine and containing with Busulfan or Treosulfan and Thiotepa should be "recommended". TBI should be avoided because of the risk of long-term complications [39].

\section{Congenital amegakaryocytic thrombocytopenia (CAMT)}

Congenital amegakaryocytic thrombocytopenia (CAMT) is an IBFM characterized by an absence of megakaryocytes in the bone marrow linked to mutation in c-MPL. This gene codes for thrombopoietin receptor. The inheritance pattern is autosomal recessive [56]. Severe form patients experience early pancytopenia onset. HSCT represents the only curative treatment. About 80 cases of HSCT in CAMT were registered in EBMT data base and were reported to the 2014 BMT tandem meetings in Dallas [57]. Some case reports or very short series were published at time.

Severe pancytopenia onset or clonal evolution (MDS or AML) appear as formal indications for HSCT. As for other IBMF syndromes, matched healthy sibling donor is the best option. Matched (10/10) unrelated donor, as well as related $6 / 6$ matched cord blood is also a reasonable option where mismatched unrelated donors (less than 10/10), haplo-identical HSCT, as well as the use of unrelated cord blood with 0,1 or 2 HLA-disparities regardless of the number of cells should be done in experimented centers within clinical prospective trials only.

IN the EBMT-cohort presented during the 2014 BMT tandem meetings, then the rate of primary graft failure appeared higher than expected for bone marrow failure. Standard myeloablative procedure based on fludarabine and either busulfan or treosulfan is recommended in case of either clonal evolution or isolated thrombocytopenia or allo-immunization [58].

\section{Dyskeratosis congenita (DC)}

Dyskeratosis congenita is a rare BMF syndrome characterized by a triad (reticulated skin hyperpigmentation, nail dystrophy and oral leukoplakia). Telomerase dysfunction, ribosome deficiency and protein biosynthesis are responsible for this disorder. Until now, HSCT has shown disappointing results mainly because of severe late effects, including graft failure, GvHD, sepsis and, more importantly the increased propensity to develop organ toxicity, namely pulmonary fibrosis, hepatic cirrhosis and veno-occlusive disease, among others [59-61]. Total body irradiation and busulfan should not be used in this setting because of the high risk of toxicity. Mismatch related or unrelated donors are still associated with a worse prognosis than HSCT from a sibling donor [62]. Fludarabine-containing non-myeloablative conditioning regimens are now increasingly used and might give better short-term results [63-66]. The literature is scarce on the subjects to draw strong statements.

BMF syndromes occur in $80 \%$ of cases and represent the main indication for HSCT. Clonal evolution (MDS or AML) is also common with DC, because of cancer predisposition [67]. A matched healthy sibling donor appears as the best option. Matched (10/10) unrelated donor, as well as related 6/6 matched cord blood is also acceptable.

Mismatch unrelated donors (less than 10/10), haploidentical HSCT, as well as the use of unrelated cord blood 
with 0,1 or 2 HLA-disparities regardless of the number of cells should be done only in experimented centers within clinical prospective trials.

This hypersensitivity to irradiation and chemotherapy translated into poor survival of patients after HSCT, using conventional standard conditioning regimen [68, 69]. Fludarabine-containing non-myeloablative conditioning regimens are now increasingly used and might give better short-term results [64-66, 70]. The overall data suggest long-term surveillance is important particularly for cancers and pulmonary complications both of which are likely to be secondary to the genetic defect that is not corrected by HSCT.

\section{Conclusion}

The group of IBMF syndromes contains a wide disease spectrum and interests few patients. The phenotypical heterogeneity associated with extra-medullary abnormalities has to be carefully evaluated before any HSCT indication since transplantation may only correct impaired hematopoiesis. If HSCT is indicated, transplantation has to be done before transfusion dependency preferentially from healthy sibling donor bone marrow. For those IBMF with clonal evolution risk, yearly marrow evaluation has to be performed and HSCT done before MDS/acute leukemia occurrence.

\section{Compliance with ethical standards}

Conflict of interest The authors declare that they have no conflict of interest.

\section{References}

1. Ghemlas I, Li H, Zlateska B, Klaassen R, Fernandez CV, Yanofsky RA, Wu J, Pastore Y, Silva M, Lipton JH, et al. Improving diagnostic precision, care and syndrome definitions using comprehensive next-generation sequencing for the inherited bone marrow failure syndromes. J Med Genet. 2015;52:575-84.

2. Zhang MY, Keel SB, Walsh T, Lee MK, Gulsuner S, Watts AC, Pritchard CC, Salipante SJ, Jeng MR, Hofmann I, et al. Genomic analysis of bone marrow failure and myelodysplastic syndromes reveals phenotypic and diagnostic complexity. Haematologica. 2015;100:42-8.

3. Alter BP. Fanconi anemia and the development of leukemia. Best Pract Res Clin Haematol. 2014;27:214-21.

4. Ameziane N, Sie D, Dentro S, Ariyurek Y, Kerkhoven L, Joenje H, Dorsman JC, Ylstra B, Gille JJ, Sistermans EA, de Winter JP. Diagnosis of Fanconi anemia: mutation analysis by next-generation sequencing. Anemia. 2012;2012:132856.

5. Bogliolo M, Surralles J. Fanconi anemia: a model disease for studies on human genetics and advanced therapeutics. Curr Opin Genet Dev. 2015;33:32-40.
6. Gluckman E, Auerbach AD, Horowitz MM, Sobocinski KA, Ash RC, Bortin MM, Butturini A, Camitta BM, Champlin RE, Friedrich W, et al. Bone marrow transplantation for Fanconi anemia. Blood. 1995;86:2856-62.

7. Guardiola P, Pasquini R, Dokal I, Ortega JJ, van Weel-Sipman M, Marsh JC, Ball SE, Locatelli F, Vermylen C, Skinner R, et al. Outcome of 69 allogeneic stem cell transplantations for Fanconi anemia using HLA-matched unrelated donors: a study on behalf of the European Group for Blood and Marrow Transplantation. Blood. 2000;95:422-9.

8. Locatelli F, Zecca M, Pession A, Morreale G, Longoni D, Di Bartolomeo P, Porta F, Fagioli F, Nobili B, Bernardo ME, et al. The outcome of children with Fanconi anemia given hematopoietic stem cell transplantation and the influence of fludarabine in the conditioning regimen: a report from the Italian pediatric group. Haematologica. 2007;92:1381-8.

9. Wagner JE, Eapen M, MacMillan ML, Harris RE, Pasquini R, Boulad F, Zhang MJ, Auerbach AD. Unrelated donor bone marrow transplantation for the treatment of Fanconi anemia. Blood. 2007;109:2256-62.

10. Deeg HJ, Socie G, Schoch G, Henry-Amar M, Witherspoon RP, Devergie A, Sullivan KM, Gluckman E, Storb R. Malignancies after marrow transplantation for aplastic anemia and Fanconi anemia: a joint Seattle and Paris analysis of results in 700 patients. Blood. 1996;87:386-92.

11. Malric A, Defachelles AS, Leblanc T, Lescoeur B, Lacour B, Peuchmaur M, Maurage CA, Pierron G, Guillemot D, d'Enghien $\mathrm{CD}$, et al. Fanconi anemia and solid malignancies in childhood: a national retrospective study. Pediatr Blood Cancer. 2015;62:463-70.

12. Masserot C, Peffault de Latour R, Rocha V, Leblanc T, Rigolet A, Pascal F, Janin A, Soulier J, Gluckman E, Socie G. Head and neck squamous cell carcinoma in 13 patients with Fanconi anemia after hematopoietic stem cell transplantation. Cancer. 2008;113:3315-22.

13. Gluckman E, Devergie A, Dutreix J. Radiosensitivity in Fanconi anaemia: application to the conditioning regimen for bone marrow transplantation. Br J Haematol. 1983;54:431-40.

14. Medeiros C, Zanis-Neto J, Pasquini R. Bone marrow transplantation for patients with Fanconi anemia: reduced doses of cyclophosphamide without irradiation as conditioning. Bone Marrow Transplant. 1999;24:849-52.

15. de la Fuente J, Reiss S, McCloy M, Vulliamy T, Roberts IA, Rahemtulla A, Dokal I. Non-TBI stem cell transplantation protocol for Fanconi anaemia using HLA-compatible sibling and unrelated donors. Bone Marrow Transplant. 2003;32:653-6.

16. Guardiola P, Socie G, Li X, Ribaud P, Devergie A, Esperou H, Richard P, Traineau R, Janin A, Gluckman E. Acute graft-versushost disease in patients with Fanconi anemia or acquired aplastic anemia undergoing bone marrow transplantation from HLAidentical sibling donors: risk factors and influence on outcome. Blood. 2004;103:73-7.

17. MacMillan ML, DeFor TE, Young JA, Dusenbery KE, Blazar BR, Slungaard A, Zierhut H, Weisdorf DJ, Wagner JE. Alternative donor hematopoietic cell transplantation for Fanconi anemia. Blood. 2015;125:3798-804.

18. Shimada A, Takahashi Y, Muramatsu H, Hama A, Ismael O, Narita A, Sakaguchi H, Doisaki S, Nishio N, Tanaka M, et al. Excellent outcome of allogeneic bone marrow transplantation for Fanconi anemia using fludarabine-based reduced-intensity conditioning regimen. Int J Hematol. 2012;95:675-9.

19. Chaudhury S, Auerbach AD, Kernan NA, Small TN, Prockop SE, Scaradavou A, Heller G, Wolden S, O'Reilly RJ, Boulad F. Fludarabine-based cytoreductive regimen and T-celldepleted grafts from alternative donors for the treatment of 
high-risk patients with Fanconi anaemia. $\mathrm{Br} \mathrm{J}$ Haematol. 2008;140:644-55.

20. de Peffault Latour R, Porcher R, Dalle JH, Aljurf M, Korthof ET, Svahn J, Willemze R, Barrenetxea C, Mialou V, Soulier J, et al. Allogeneic hematopoietic stem cell transplantation in Fanconi anemia: the European Group for Blood and Marrow Transplantation experience. Blood. 2013;122:4279-86.

21. Stepensky P, Shapira MY, Balashov D, Trakhtman P, Skorobogatova E, Rheingold L, Brooks R, Revel-Vilk S, Weintraub M, Stein J, et al. Bone marrow transplantation for Fanconi anemia using fludarabine-based conditioning. Biol Blood Marrow Transplant. 2011;17:1282-8.

22. Yabe H, Inoue H, Matsumoto M, Hamanoue S, Koike T, Ishiguro H, Koike H, Suzuki K, Kato S, Kojima S, et al. Allogeneic haematopoietic cell transplantation from alternative donors with a conditioning regimen of low-dose irradiation, fludarabine and cyclophosphamide in Fanconi anaemia. Br J Haematol. 2006;134:208-12.

23. MacMillan ML, Wagner JE. Haematopoeitic cell transplantation for Fanconi anaemia-when and how? Br J Haematol. 2010;149:14-21.

24. Gluckman E, Ruggeri A, Volt F, Cunha R, Boudjedir K, Rocha V. Milestones in umbilical cord blood transplantation. Br J Haematol. 2011;154:441-7.

25. Bacigalupo A, Socie G, Schrezenmeier H, Tichelli A, Locasciulli A, Fuehrer M, Risitano AM, Dufour C, Passweg JR, Oneto $\mathrm{R}$, et al. Bone marrow versus peripheral blood as the stem cell source for sibling transplants in acquired aplastic anemia: survival advantage for bone marrow in all age groups. Haematologica. 2012;97:1142-8.

26. Eapen M, Le Rademacher J, Antin JH, Champlin RE, Carreras J, Fay J, Passweg JR, Tolar J, Horowitz MM, Marsh JC, Deeg HJ. Effect of stem cell source on outcomes after unrelated donor transplantation in severe aplastic anemia. Blood. 2011;118:2618-21.

27. Schrezenmeier H, Passweg JR, Marsh JC, Bacigalupo A, Bredeson CN, Bullorsky E, Camitta BM, Champlin RE, Gale RP, Fuhrer M, et al. Worse outcome and more chronic GVHD with peripheral blood progenitor cells than bone marrow in HLA-matched sibling donor transplants for young patients with severe acquired aplastic anemia. Blood. 2007;110:1397-400.

28. Gluckman E. Improving survival for Fanconi anemia patients. Blood. 2015;125:3676.

29. Talbot A, Peffault de Latour R, Raffoux E, Buchbinder N, Vigouroux S, Milpied N, Leblanc T, Soulier J, Michallet M, Socie G. Sequential treatment for allogeneic hematopoietic stem cell transplantation in Fanconi anemia with acute myeloid leukemia. Haematologica. 2014;99:e199-200.

30. Kohli-Kumar M, Morris C, DeLaat C, Sambrano J, Masterson M, Mueller R, Shahidi NT, Yanik G, Desantes K, Friedman DJ, et al. Bone marrow transplantation in Fanconi anemia using matched sibling donors. Blood. 1994;84:2050-4.

31. Kostmann R. Infantile genetic agranulocytosis; agranulocytosis infantilis hereditaria. Acta Paediatr Suppl. 1956;45:1-78.

32. Bellanne-Chantelot C, Clauin S, Leblanc T, Cassinat B, Rodrigues-Lima F, Beaufils S, Vaury C, Barkaoui M, Fenneteau $\mathrm{O}$, Maier-Redelsperger $\mathrm{M}$, et al. Mutations in the ELA2 gene correlate with more severe expression of neutropenia: a study of 81 patients from the French Neutropenia Register. Blood. 2004;103:4119-25.

33. Germeshausen M, Zeidler C, Stuhrmann M, Lanciotti M, Ballmaier M, Welte K. Digenic mutations in severe congenital neutropenia. Haematologica. 2010;95:1207-10.

34. Person RE, Li FQ, Duan Z, Benson KF, Wechsler J, Papadaki HA, Eliopoulos G, Kaufman C, Bertolone SJ, Nakamoto B, et al.
Mutations in proto-oncogene GFI1 cause human neutropenia and target ELA2. Nat Genet. 2003;34:308-12.

35. Sayour EJ, Carter C, Eldjerou L. A novel ELANE gene mutation in a patient with severe congenital neutropenia and intermittent thrombocytopenia. Pediatr Blood Cancer. 2015;62:1870-1.

36. Touw IP. Game of clones: the genomic evolution of severe congenital neutropenia. Hematology Am Soc Hematol Educ Program. 2015;2015:1-7.

37. Dale DC, Cottle TE, Fier CJ, Bolyard AA, Bonilla MA, Boxer LA, Cham B, Freedman MH, Kannourakis G, Kinsey SE, et al. Severe chronic neutropenia: treatment and follow-up of patients in the Severe Chronic Neutropenia International Registry. Am J Hematol. 2003;72:82-93.

38. Bonilla MA, Gillio AP, Ruggeiro M, Kernan NA, Brochstein JA, Abboud M, Fumagalli L, Vincent M, Gabrilove JL, Welte K, et al. Effects of recombinant human granulocyte colony-stimulating factor on neutropenia in patients with congenital agranulocytosis. N Engl J Med. 1989;320:1574-80.

39. Dalle JH, Donadieu J, Paillard C, Rialland F, Schneider P, Sicre De Fontbrune F, Hichri Y, Neven B, Yakoub-Agha I, Sfgm TC. [SFGM-TC recommendation on indications for allogeneic stem cell transplantation in children with congenital neutropenia]. Pathol Biol (Paris). 2014;62:209-11.

40. Ferry C, Ouachee M, Leblanc T, Michel G, Notz-Carrere A, Tabrizi R, Flood T, Lutz P, Fischer A, Gluckman E, Donadieu J. Hematopoietic stem cell transplantation in severe congenital neutropenia: experience of the French SCN register. Bone Marrow Transplant. 2005;35:45-50.

41. Fioredda F, Iacobelli S, van Biezen A, Gaspar B, Ancliff P, Donadieu J, Aljurf M, Peters C, Calvillo M, Matthes-Martin S, et al. Stem cell transplantation in severe congenital neutropenia: an analysis from the European Society for Blood and Marrow Transplantation. Blood. 2015;126:1885-92.

42. Oshima K, Hanada R, Kobayashi R, Kato K, Nagatoshi Y, Tabuchi K, Kato S. Hematopoietic Stem Cell Transplantation Committee of the Japanese Society of Pediatric H: hematopoietic stem cell transplantation in patients with severe congenital neutropenia: an analysis of 18 Japanese cases. Pediatr Transplant. 2010;14:657-63.

43. Donadieu J, Leblanc T, Bader Meunier B, Barkaoui M, Fenneteau O, Bertrand Y, Maier-Redelsperger M, Micheau M, Stephan JL, Phillipe N, et al. Analysis of risk factors for myelodysplasias, leukemias and death from infection among patients with congenital neutropenia. Experience of the French Severe Chronic Neutropenia Study Group. Haematologica. 2005;90:45-53.

44. Osone S, Imamura T, Fukushima-Nakase Y, Kitamura-Masaki A, Kanai S, Imai T, Imashuku S, Kuroda H. Case reports of severe congenital neutropenia treated with unrelated cord blood transplantation with reduced-intensity conditioning. J Pediatr Hematol Oncol. 2016;38:49-52.

45. Anderson JE, Gooley TA, Schoch G, Anasetti C, Bensinger WI, Clift RA, Hansen JA, Sanders JE, Storb R, Appelbaum FR. Stem cell transplantation for secondary acute myeloid leukemia: evaluation of transplantation as initial therapy or following induction chemotherapy. Blood. 1997;89:2578-85.

46. Cassinat B, Bellanne-Chantelot C, Notz-Carrere A, Menot ML, Vaury C, Micheau M, Bader-Meunier B, Perel Y, Leblanc T, Donadieu J, Chomienne C. Screening for G-CSF receptor mutations in patients with secondary myeloid or lymphoid transformation of severe congenital neutropenia. A report from the French neutropenia register. Leukemia. 2004;18:1553-5.

47. Germeshausen M, Ballmaier M, Schulze H, Welte K, Flohr T, Beiske K, Storm-Mathisen I, Abrahamsen TG. Granulocyte colony-stimulating factor receptor mutations in a patient with acute lymphoblastic leukemia secondary to severe congenital neutropenia. Blood. 2001;97:829-30. 
48. Ebihara Y, Ishikawa K, Mochizuki S, Tanaka R, Manabe A, Iseki T, Maekawa T, Tsuji K. Allogeneic stem cell transplantation for patients with acute myeloid leukaemia developing from severe congenital neutropenia. Br J Haematol. 2014;164:459-61.

49. Dror Y, Freedman MH. Shwachman-diamond syndrome. Br J Haematol. 2002;118:701-13.

50. Boocock GR, Morrison JA, Popovic M, Richards N, Ellis L, Durie PR, Rommens JM. Mutations in SBDS are associated with Shwachman-Diamond syndrome. Nat Genet. 2003;33:97-101.

51. Donadieu J, Fenneteau O, Beaupain B, Beaufils S, Bellanger F, Mahlaoui N, Lambilliotte A, Aladjidi N, Bertrand Y, Mialou V, et al. Classification of and risk factors for hematologic complications in a French national cohort of 102 patients with Shwachman-Diamond syndrome. Haematologica. 2012;97:1312-9.

52. Dror Y, Donadieu J, Koglmeier J, Dodge J, Toiviainen-Salo S, Makitie O, Kerr E, Zeidler C, Shimamura A, Shah N, et al. Draft consensus guidelines for diagnosis and treatment of Shwachman-Diamond syndrome. Ann NY Acad Sci. 2011;1242:40-55.

53. Sauer M, Zeidler C, Meissner B, Rehe K, Hanke A, Welte K, Lohse P, Sykora KW. Substitution of cyclophosphamide and busulfan by fludarabine, treosulfan and melphalan in a preparative regimen for children and adolescents with Shwachman-Diamond syndrome. Bone Marrow Transplant. 2007;39:143-7.

54. Fagioli F, Quarello P, Zecca M, Lanino E, Corti P. avre F, Ripaldi M, Ramenghi U, Locatelli F, Prete A: haematopoietic stem cell transplantation for Diamond Blackfan anemia: a report from the Italian association of paediatric haematology and oncology registry. Br J Haematol. 2014; 165:673-81.

55. Vlachos A, Muir E. How I treat Diamond-Blackfan anemia. Blood. 2010;116:3715-23.

56. Ballmaier M, Germeshausen M. Congenital amegakaryocytic thrombocytopenia: clinical presentation, diagnosis, and treatment. Semin Thromb Hemost. 2011;37:673-81.

57. Dalle JH, Fahd M. Allogeneic stem cell transplantation in amegacaryocytosis: results of a retrospective study in EBMT centers. Biol Blood Marrow Transplant. 2014;20:S81-2.

58. Mahadeo KM, Tewari P, Parikh SH, Driscoll TA, Page K, Martin PL, Kurtzberg J, Prasad VK. Durable engraftment and correction of hematological abnormalities in children with congenital amegakaryocytic thrombocytopenia following myeloablative umbilical cord blood transplantation. Pediatr Transplant. 2015;19:753-7.

59. de la Fuente J, Dokal I. Dyskeratosis congenita: advances in the understanding of the telomerase defect and the role of stem cell transplantation. Pediatr Transplant. 2007;11:584-94.

60. Dror Y, Freedman MH, Leaker M, Verbeek J, Armstrong CA, Saunders FE, Doyle JJ. Low-intensity hematopoietic stem-cell transplantation across human leucocyte antigen barriers in dyskeratosis congenita. Bone Marrow Transplant. 2003;31:847-50.

61. Rocha V, Devergie A, Socie G, Ribaud P, Esperou H, Parquet N, Gluckman E. Unusual complications after bone marrow transplantation for dyskeratosis congenita. $\mathrm{Br} \mathrm{J}$ Haematol. 1998;103:243-8.

62. Gadalla SM, Sales-Bonfim C, Carreras J, Alter BP, Antin JH, Ayas M, Bodhi P, Davis J, Davies SM, Deconinck E, et al. Outcomes of allogeneic hematopoietic cell transplantation in patients with dyskeratosis congenita. Biol Blood Marrow Transplant. 2013;19:1238-43.

63. Bizzetto R, Bonfim C, Rocha V, Socie G, Locatelli F, Chan K, Ramirez O, Stein J, Nabhan S, Miranda E, et al. Outcomes after related and unrelated umbilical cord blood transplantation for hereditary bone marrow failure syndromes other than Fanconi anemia. Haematologica. 2011;96:134-41.

64. Dietz AC, Orchard PJ, Baker KS, Giller RH, Savage SA, Alter BP, Tolar J. Disease-specific hematopoietic cell transplantation: nonmyeloablative conditioning regimen for dyskeratosis congenita. Bone Marrow Transplant. 2011;46:98-104.

65. Nishio N, Takahashi Y, Ohashi H, Doisaki S, Muramatsu H, Hama A, Shimada A, Yagasaki H, Kojima S. Reduced-intensity conditioning for alternative donor hematopoietic stem cell transplantation in patients with dyskeratosis congenita. Pediatr Transplant. 2011;15:161-6.

66. Vuong LG, Hemmati PG, Neuburger S, Terwey TH, Vulliamy T, Dokal I, le Coutre P, Dorken B, Arnold R. Reduced-intensity conditioning using fludarabine and antithymocyte globulin alone allows stable engraftment in a patient with dyskeratosis congenita. Acta Haematol. 2010;124:200-3.

67. Savage SA, Alter BP. Dyskeratosis congenita. Hematol Oncol Clin North Am. 2009;23:215-31.

68. Amarasinghe K, Dalley C, Dokal I, Laurie A, Gupta V, Marsh J. Late death after unrelated-BMT for dyskeratosis congenita following conditioning with alemtuzumab, fludarabine and melphalan. Bone Marrow Transplant. 2007;40:913-4.

69. Brazzola P, Duval M, Fournet JC, Gauvin F, Dalle JH, Champagne J, Champagne MA. Fatal diffuse capillaritis after hematopoietic stem-cell transplantation for dyskeratosis congenita despite low-intensity conditioning regimen. Bone Marrow Transplant. 2005;36:1103-5 (author reply 1105).

70. Ayas M, Nassar A, Hamidieh AA, Kharfan-Dabaja M, Othman TB, Elhaddad A, Seraihy A, Hussain F, Alimoghaddam K, Ladeb $\mathrm{S}$, et al. Reduced intensity conditioning is effective for hematopoietic SCT in dyskeratosis congenita-related BM failure. Bone Marrow Transplant. 2013;48:1168-72. 